\title{
Dogfennel (Eupatorium capillifolium): Biology and Control ${ }^{1}$
}

\section{J. A. Ferrell and G. E. MacDonald ${ }^{2}$}

Dogfennel (Eupatorium capillifolium) is an aggressive native perennial that is found throughout much of the Southeast. Dogfennel is particularly troublesome in unimproved or overgrazed pastures where it adds to the decline of forage yield and quality. Although generally considered to be only unsightly, the leaves contain low levels of the toxin tremitol, which causes dehydration when ingested by cattle. Cattle do not normally feed on dogfennel, but it may be eaten when more suitable forages are lacking. Dogfennel is currently the number one most commonly occurring pasture weed in Florida.

\section{Biology}

Dogfennel growth is frequently from overwintering rosettes, but seeds will also sprout and grow when soil temperatures reach $65^{\circ} \mathrm{F}$. The growth will generally consist of a single, non-branching shoot that can exceed 8 feet in height. The leaves are very thin (Figure 1) and emit a strong odor when crushed. Near Gainesville, Florida, the lifecycle will resemble:

$\begin{array}{ll}\text { Dormancy: } & \text { January to March } \\ \text { Bolting: } & \text { April to June } \\ \text { Flowering: } & \text { September to October } \\ \text { Fruiting: } & \text { November } \\ \text { Seed dispersal: } & \text { November to } \\ & \text { December }\end{array}$

Seeds are surrounded with hairs (similar to dandelion) allowing effective dispersal by wind. Therefore, bare areas in pastures are ideal environments for wind blown seed to become established.

In addition to growth from seed, dogfennel can spread from underground rootstocks. These rootstocks arise from the main taproot and grow laterally in all directions. This process will result in the production of distinct plant colonies in only three years.

1. This document is SS-AGR-224 one of a series of the Agronomy Department, Florida Cooperative Extension Service, Institute of Food and Agricultural Sciences, University of Florida. Published August, 2004. Visit the EDIS Web Site at http://edis.ifas.ufl.edu.

2. J.A. Ferrell, assistant professor, Agronomy Department; G.E. MacDonald, assistant professor, Agronomy Department; Florida Cooperative Extension Service, Institute of Food and Agricultural Sciences, University of Florida, Gainesville, FL 32611.

The use of trade names in this publication is solely for the purpose of providing specific information. UF/IFAS does not guarantee or warranty the products named, and references to them in this publication does not signify our approval to the exclusion of other products of suitable composition. All chemicals should be used in accordance with directions on the manufacturer's label.

The Institute of Food and Agricultural Sciences (IFAS) is an Equal Employment Opportunity - Affirmative Action Employer authorized to provide research, educational information and other services only to individuals and institutions that function without regard to race, creed, color, religion, age, disability, sex, sexual orientation, marital status, national origin, political opinions or affiliations. For information on obtaining other extension publications, contact your county Cooperative Extension Service office. Florida Cooperative Extension Service / Institute of Food and Agricultural Sciences / University of Florida / Larry R. Arrington, Interim Dean 


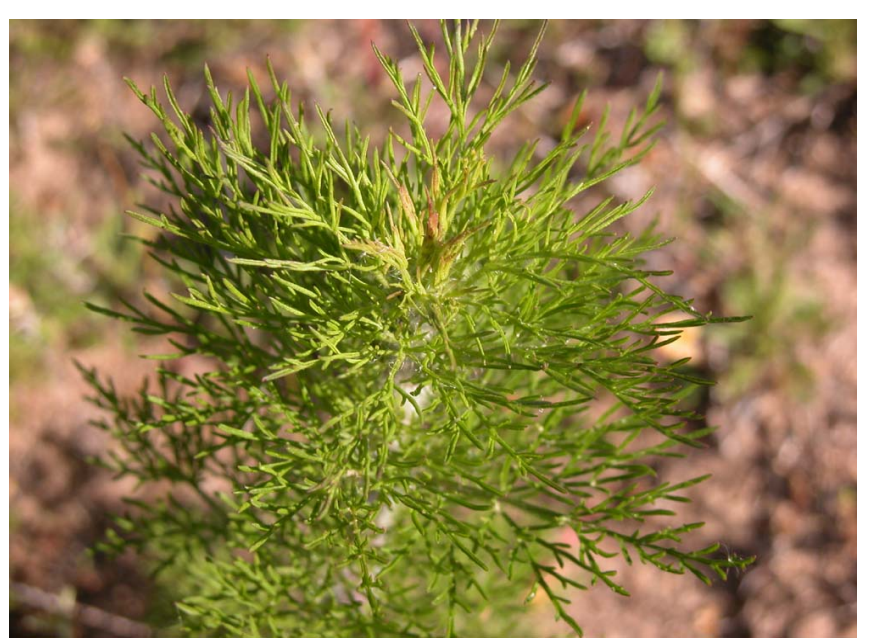

Figure 1. Dogfennel (Eupatorium capillifolium) showing finely dissected leaves.



Figure 2. Dogfennel colony resulting from lateral spread from rootstocks.

\section{Control}

The first step in managing dogfennel is prevention. Maintaining a dense pasture with proper fertility and grazing management will greatly discourage the encroachment of dogfennel. A dense sward will prevent light from reaching the soil surface, discouraging seed germination, and will strongly compete with weed seedlings if germination occurs. Not only will pasture management give greater quantities of high quality forage, but will also reduce weed pressure.

Another practice used to control dogfennel, with limited success, is mowing. Due to the large rootstocks that exist below ground, rapid regrowth after mowing is commonly observed (Figure 2). But, these rootstocks may be depleted if multiple mowings throughout the growing season are used. The limitation to this method for dogfennel control is that it often becomes cost prohibitive before adequate levels of control are achieved. Tim Hewitt, Agriculture Economist at the University of Florida, has calculated that it will routinely cost $\$ 8$ per acre to mow pastures. However, mowing in the fall prior to seed production can be beneficial to reduce seed production and dissemination.

The use of herbicides has traditionally been the most successful and cost effective means of controlling dogfennel. Research conducted at the University of Florida has shown that Remedy (triclopyr), Crossbow (2,4-D + triclopyr) and Weedmaster (2,4-D + dicamba) are highly effective for controlling dogfennel. The advantage of these herbicides is that they may be applied to established pastures without injuring forage grasses. Conversely, glyphosate applied at 1.5 and $3.0 \mathrm{lbs}$ active ingredient per acre will also provide greater than $90 \%$ control (this is equal to 2 or $4 \mathrm{pt} / \mathrm{A}$ Roundup Weathermax and 3 or 6 pt/A of Glyphomax and other $4 \mathrm{lb} / \mathrm{gal}$ glyphosates). Glyphosate must be spot applied to avoid severe injury to surrounding forage grasses.

Dogfennel control is closely related to plant size at time of application. The authors have observed that as dogfennel grows the amount of herbicide used to control it must correspondingly increase. For example:
0-12 inches:

12-24 inches:

24-30 inches:

$>30$ inches:

\section{2 pt Weedmaster}

3 pt Weedmaster

1 pt Weedmaster +1 pt Remedy

2 pt (or more) Remedy
Additionally, mowing prior to herbicide application is often beneficial. Presented in Table 1 are control data when dogfennel was mowed at a height of 3 to 4 inches, and allowed to regrow to 6 inches before herbicide application. 
Table 1.

\begin{tabular}{|c|c|c|c|}
\hline Herbicide & Rate & \multicolumn{2}{|c|}{$\%$ control } \\
\hline Weedmaster & $2 \mathrm{pt}$ & 95 & 50 \\
\hline Weedmaster & $4 \mathrm{pt}$ & 95 & 70 \\
\hline Crossbow & $2 \mathrm{qt}$ & 98 & 60 \\
\hline Crossbow & $4 \mathrm{qt}$ & 99 & 85 \\
\hline
\end{tabular}

Mowing will ensure that all plants are at the same growth stage at time of herbicide application and give a more uniform response. Mowing is particularly important when trying to control large dogfennel plants that are several months old. As a plant ages, the ability of a leaf to absorb herbicide can become greatly reduced. Therefore, mowing then spraying regrowth will often ensure that succulent young leaves will be treated.

Herbicides such as Velpar (hexazinone) and Cimarron (metsulfuron) can also be applied in the fall for dogfennel control. However, these herbicides are generally less effective, and more variable, than the other herbicides listed in this publication.

Before applying any herbicide it is important to read the product label to ensure that each herbicide can be applied without adverse crop injury. Additionally, all grazing and haying restrictions must be observed regardless of which herbicide, or herbicide combination, is used. 